\title{
Engaging the World From the English Classroom
}

\section{Junko Chujo \\ Tokyo Denki University}

\section{Reference Data:}

Chujo, J. (2020). Engaging the world from the English classroom. In P. Clements, A. Krause, \& R. Gentry (Eds.), Teacher efficacy, learner agency. Tokyo: JALT. https://doi.org/10.37546/JALTPCP2019-47

Many professionals who have been involved in university English education in Japan have wondered how to foster students' active engagement with the rest of the world from the classroom. In this paper, the author describes a classroom-based project to help students lower their inhibition towards using English and motivate them to improve their English skills through a special focus on connecting to the world in their daily life. Students chose one available foreign snack as representative of a nation, researched the country or the product, and conducted poster language, research, and presentation skills and enable them to successfully complete the project. A post-instructional questionnaire revealed that this simple project had a positive impact on various affective variables, especially on students' interest in other countries and cultures, their desire to communicate in English, and their motivation to improve English communication skills.

本研究は、日本人大学生の国際性に関わる情意面の開発により、英語使用への意欲老高办、通用性のより高い英語を身に つけさせるためのプロジエクト型の教材開発を目的としている。この目的を具体化した教材の導入によ以学生の国際性と英 語使用に関しての情意面の变容を检証した。プロジエクトは、学生が身の回りにある外国のお菓子を選握し、その国やその商 品について調ベ、小グループによるポスター発表を行う活動から成る。活動の特徵は、斉授業形態の授業においても学生の 情意面に配慮し心理面での不安を低くする点学生が自らの生活と外国とのつながをを体験を通し実感し、学生個々の経験や

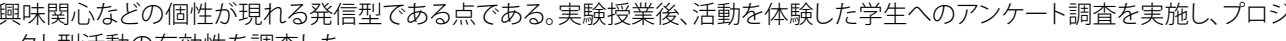
エクト型活動の有効性を調査した。 iving in Japan, many students may feel that they have no need of English for $\checkmark$ practical daily use. Even though they are surrounded by various representations of international cultures, many often remain unaware that they already live in a global community and do not realize that English language skills can help them in their future career and personal life. The question for educators in Japan is how to foster the connection between Japanese students and the global community from the classroom and lead them to realize the importance of improving their English language skills.

To tackle this issue, the instructor developed an affect-oriented, classroom-based project for Japanese university English learners. The aims were to enhance students' motivation to learn English, increase their interest in practical English use, and foster their willingness to communicate with others in English by lowering their affective barriers towards English communication. These aims were achieved by accessing students' affective domain through a project designed to help them realize the close connection between their daily life and the globalized world. The theme of this project was "an international potluck snack party." Students selected one foreign snack as representative of a nation, researched some aspect of that nation, and conducted individual poster presentations to share their mini-research findings with their peers.

\section{Motivation and English Language Learning}

In 2011, Hamada conducted a study that followed Japanese students' motivation flow in terms of their English learning from junior high school to the university level. Each year during the time preceding a major test there was an increase in motivation, but each year following a major test there was a decrease in motivation. Miura (2010) claimed that this increase in motivation is often the result of a desire to pass entrance examinations, suggesting that many students are extrinsically motivated by the required English tests throughout their junior high and high school years. After students pass university entrance examinations, the motivation that had been their driving force to learn English tends to decline, especially for non-English majors. In view of this, it would seem that 
rekindling students' intrinsic motivation is one of the major factors in sustaining their motivation to study English at the tertiary level in Japan.

Bloom's (1956) well-known taxonomy of three learning domains categorizes learning into the affective domain (attitudes), the cognitive domain (knowledge), and the psychomotor domain (skills). The affective domain relates to how a person thinks and feels, thus motivation falls under this domain. Richard-Amarto (2010) affirms that "attitudes, motivation, and level of anxiety are central to the affective domain" (italics in original; p.153) and that these variables, depending on the context in which they operate, can have either a positive or a negative influence on $\mathrm{L} 2$ learning. Indeed, the affective domain is generally considered "very important in education and training" (Heinich, Molenda, \& Russell, 1993, p.104).

In a lecture on instructional design (ID), Kogo (2015) explained each of the three domains of learning and concluded that the affective domain is the most important. As Yashima (2003) stresses, "The language learning environment needs to help students to become autonomous learners who find personal meaning in learning English as well as in communication with dissimilar others" (p. 1). This can be achieved through a broad range of instructional tools that motivate learners intrinsically, helping them realize that their English ability can be used not only to pass examinations, but also for actual communication and engagement with the rest of the world. With this in mind, the current project was created to help students realize their connection to the rest of the world and encourage them to use this connection to communicate in English.

\section{Activity Design and Development \\ Key Criteria}

The project was designed for two classes of Japanese engineering majors, with a total of 45 students. Class A was composed of 27 third- and fourth-year students (this was a $2^{\text {nd }}$ year retake class) and Class B was composed of 18 first-year students. Class A consisted mostly of students who failed the class previously, plus some students who had chosen not to take the class the previous year. Class B was composed of the students that scored the lowest in the university's placement test. The instructor's classroom observation prior to the launch of the project revealed that the students' involvement in the class was passive and that their motivation and interest for learning English was low. For the development of the project, three elements were made key priorities (see Table 1). These priorities are the foci of the present project, and as such, this paper does not comment on the project's impact on students' language, presentation, or research skills, even though these skills were targeted throughout the instruction.

Table 1. Key Priorities for the Development of the Project

Goals Methods for achieving goals

Give high priority orientation.

Foster global perspectives from the classroom and facilitate students'

Utilize students' experience-based activities. to learners' affective language learning.

1. Create a secure, comfortable, and enjoyable environment and foster a confident and positive attitude toward English in order to lower learners' anxiety level and optimize learning.

2. Ignite students' intrinsic motivation to learn English by nurturing students' interests, helping them to realize the importance of improving their English skills, and fostering in them a desire to communicate in English.

3. Lead students to find joy in communicating in English and change their attitude toward learning English.

1. Help students to realize their connection to other parts of the world and encourage the active use of English with people from different cultural backgrounds.

2. Serve as a first step to global education and to developing students who can act independently with a global view.

1. Engage students in an activity where they actively seek out international influence in their own sphere of experience.

2. Relate the research topic to students' lives and give the students control over the research topic. This provides a creative challenge, an opportunity for individual expression, and an active classroom environment.

The key elements for the project are interrelated. It would be ideal if, through this project, students could obtain an affective outcome and growth similar to that achieved by students who have studied abroad.

\section{Project Description}

The project was designed for a total of five instruction sessions at 1-week intervals. Table 2 shows the project schedule. 
Table 2. Project Schedule

Session 1: Introduction of the project (Worksheet 1), Take home assignment:

Select/buy the snack

Session 2: Review of requirements (Worksheet 1), Search for the snack and country

Session 3: Preparation of the script and poster (Worksheet 2)

Session 4: Preparation of the script and poster (Worksheet 2), Presentation rehearsal

Session 5: Presentation session (Worksheet 3), Post-project questionnaire

(In sessions 2-4, students work at their own pace in class and take home the assignment)

First, two worksheets were designed based on the key elements presented in the previous section, (see Appendices A and B). Each had a different aim, however, both were designed so that students could follow each activity's directions step-by-step autonomously on their own or with the assistance of their peers.

Worksheet 1 was designed to help the participants understand the project through language skills reinforcement. The activities consisted of three sections. Section A (Expression) contained instructions on relevant expressions and the presentation. Section B (Dialogue) had three subcategories. The first, Dictation, was an explanation of the project via a dialogue and fill-in-the-blank activity. This section included instructions regarding relevant international background knowledge (such as food, culture, religion, dietary requirements, allergies, veganism, etc.). The second category, Comprehension Check, was designed to make sure learners understood the requirements of the presentation. The third category, Summary, required students to write an overview of the presentation they would give. Section C (Let's Practice the Presentation) gave students sample scripts they could use as practice presentations. Through these activities, students came to understand the assignment requirements.

The intent of Worksheet 2 was to help each student systematically prepare for their own presentation according to the instructional information gained through the dialogue section in Worksheet 1 . The activity began with students double-checking the requirements of the project. This included a section to prepare students to write their presentation script and design their poster presentation.

During the first session, students worked on the activities in Worksheet 1. For this assignment, students were asked to purchase a snack item from another country. To keep expenditures fair and regulated, the price range was set between 100 and 300 yen. Selecting/buying the snack was their homework assignment for the first session. During the second session, students researched their selected item and country of origin. During the third and fourth sessions, students worked on the script and poster. It was left to the students to decide whether to start working on the script or the poster first.

Students were required to conduct an individual two- to four-minute presentation during the fifth session using their selected item and a visual aid (an A3 size poster). The presentation requirements were flexible enough for each student to show their individuality and creativity. The topic could be on the selected item, the selected item plus an introduction of the country in general, or it could focus on a specific aspect related to their life or interests. Students were assigned to groups and conducted their presentation with an audience of four to five group members. Each group required three assigned roles: (a) a group leader to chair the session, (b) an assistant to keep time, and (c) an assistant to hold the poster during the presentation. Each group leader introduced a student. The student then presented their poster and selected item. After each presentation, students completed Worksheet 3 (see Appendix C).

After each presentation, time was given for questions and answers. Before moving on to the next presenter, each group member wrote out a comment card for the presentation. After all the members presented, students selected the best presenter from each group and wrote down the reason for their selection. Then they shared and enjoyed the snacks. The project concluded with these student presentations and the potluck snack party.

\section{Implementation, Examination, and Results}

To examine the pedagogical effectiveness and detect the key influential features on students' affective domain, a written questionnaire was conducted after the presentation session. This contained some fixed and open-ended questions about conducting the project, followed by 16 Likert-scale questions, and a final open-ended question. All the participants gave informed consent, and the project was cleared with the university's institutional review board. The first question examined students' initial reaction toward the assignment (see Table 3). 
Chujo: Engaging the World From the English Classroom

Table 3. Results of "Were You Nervous When the Assignment Was Announced?" $(N=45)$

\begin{tabular}{lcccccc}
\hline Class & $\begin{array}{c}\text { strongly } \\
\text { disagree }\end{array}$ & disagree & neutral & agree & $\begin{array}{c}\text { strongly } \\
\text { agree }\end{array}$ & N/A \\
\hline A & 5 & 3 & 8 & 9 & 2 & 0 \\
B & 1 & 7 & 4 & 4 & 1 & 1 \\
\hline
\end{tabular}

Note. Class A $(\mathrm{n}=27)$, Class B $(\mathrm{n}=18)$

These results reveal that students' initial feelings about the project varied greatly. In Class A, 40\% were nervous about the project (agree and strongly agree answers combined); in Class B. $45 \%$ were not nervous about the project (disagree and strongly disagree answers combined). This answer had the widest spread among all the question items.

The item's cost was also investigated. The regulated price for the item was between 100 and 300 yen. In spite of this, some students from each class brought items that exceeded the maximum amount. The average price spent by Class B was over the 300 yen maximum; the average spent by Class A fell within the regulated range. It was noted that one student in Class A who had missed three classes during the project brought a 2000 yen item. Setting the price range required deep consideration given that extra expenses for the class could burden students, posing a negative affective influence. Students' impressions of the set price, however, suggest the price posed no negative affective effects. The majority were neutral regarding the price of the item (78\% of the students in Class A and 56\% in Class B), followed by those who felt that it was inexpensive or very inexpensive.

The next question asked how students decided upon the item-whether they chose the country then found an item to buy or whether they bought the item then set the country based on what they bought. Class A was nearly evenly divided between those that chose the country first (41\%) versus those that selected the item first (48\%). Class B, however, had a larger difference between those that chose the country first (61\%) versus those that chose the item first (33\%). The results reveal that individuals approached the task differently and show the validity of the project style in allowing students to think critically about how to handle the assignment on their own.

In addition to finding out how students made their item choice, $\mathrm{I}$ also sought to discover which countries students chose. Table 4 shows the variety of countries that students selected.
Table 4. Selected Items by Country of Origen $(N=45)$

\begin{tabular}{lcc}
\hline & \multicolumn{2}{c}{ Number } \\
\cline { 2 - 3 } Country & Class A & Class B \\
\hline The US & 6 & 2 \\
England & 5 & 2 \\
China & 3 & 2 \\
Korea & & \\
France & 2 & 3 \\
Austria & 1 & 2 \\
Belgium & 1 & 2 \\
Germany & 1 & 2 \\
The Netherlands & & 2 \\
Italy & 1 & \\
Switzerland & 1 & \\
Australia & 1 & \\
Indonesia & 1 & \\
Malaysia & & \\
Ghana & 1 & \\
Japan & 2 & \\
\hline
\end{tabular}

Note. One student in Class B brought 2 items.

European countries and the US. made up the majority of countries. One student mistakenly brought a Japanese snack. Students found the items in convenience stores, supermarkets, campus stores, international shops, and online, all of which are within reach in their daily lives. Students' reasons for their selection varied: "favorite country," "recommendation," "favorite snack," "had a memory of it," "just saw it in the store," "within the budget," "wanted to eat it," "nice package," and "found it at home."

I also asked students how much time it took them to prepare the poster and the script. Class A answered that the poster preparation took between 30 and 180 minutes, with an average of 88 minutes; the script preparation took between 25 and 240 minutes, with 
an average of 75 minutes. Class B answered that the poster preparation took between 5 and 120 minutes with an average of 46 minutes; the script preparation took between 30 and 150 minutes, with an average of 64 minutes. The time spent for preparation of the presentation varied greatly for each student and between the classes. In-class observation revealed that the time provided in class was not enough to complete the project. Nevertheless, students came to the class with very attractive, unique posters and typed or neatly written scripts on the day of presentations.

\section{Students' Responses}

The remaining 16 questions were about the preparation, presentation, and postpresentation phases. The participants evaluated their experience on a 5-point Likert scale $(1=$ strongly disagree, $2=$ disagree, $3=$ neutral, $4=$ agree, $5=$ strongly agree $)$. Question 12 had only two choices: disagree or agree. The complete questionnaire results are in Appendix D.

Regarding knowledge of the country, only students' initial knowledge of the selected country varied between classes (Q1); in other items, both classes showed similar tendencies. Both Class A (92\%) and Class B (95\%) either agreed or strongly agreed that they gained knowledge about the selected item's country of origin (Q2). They also learned about their peers' countries (Q 6). It is apparent that the majority of students gained knowledge of other countries through this project experience.

Students not only gained knowledge about different countries, but also came to feel a closeness to their presented country (Q3). Class A (89\%) and Class B (84\%) agreed or strongly agreed that they also increased their closeness to the countries their peers presented (Q5). This suggests that both their own and their peers' presentations were a powerful means for instilling a feeling of closeness to another country or its culture. Class A (78\%) and Class B (67\%) agreed or strongly agreed that they also felt an interest in the countries, cultures, or languages of the countries that their group members presented (Q13).

The small group presentation was designed to reduce students' anxiety and create a comfortable atmosphere for communication. However, responses to Q9 revealed that they felt nervous about the English presentation. Even though they were nervous responses to Q4 show that they were able to do the presentation as they had planned and prepared. They felt that they conducted their presentation successfully (Q4) and that their peers learned about the country they had selected (Q7). Students experienced a sense of accomplishment following the presentation (Q10). Although responses to Q16 show that students felt that they could do better next time, responses to Q14 show that they gained something through the process of working on the project. The majority had a feeling of accomplishment following the project and sensed that their group members understood and showed interest in what was presented. Class A (85\%) and

Class B (89\%) agreed or strongly agreed that they enjoyed the presentation session (Q11) The responses show that their interaction created a change in their affective domain by increasing their interest in other parts of the world.

The most important finding was that following the project, students responded that their desire or willingness to communicate in English was high. Class A (89\%) and Class B (89\%) agreed or strongly agreed with Q15: "Do you think you would like to be able to communicate more in English?" Also, most students agreed or strongly agreed that the project experience was good for communicating with foreigners (Q14). This proved the success of the project's aim of motivating, through the affective domain, their desire to use English.

After the presentation, students exchanged the snacks and most students tried them (Q12). I observed that by the time snacks were exchanged, the atmosphere was very positive. Students were socializing even though they were not acquainted when the groups were initially assigned. In parentheses next to the questions, many students left a comment about the foreign snacks; the majority commented that the items were too sweet or that most students in their group brought sweet snacks.

The final open-ended question was designed to examine what impression the instruction left on students after the project. Students could write either in English or Japanese. Comments revealed the effectiveness of the project on their affective domain. Comments covered elements of the overall project, the presentation, English communication, and their personal relationships with other countries in their daily life (see Figure 1).

Students had positive comments regarding the activity and many were pleasantly surprised that they were able to compose a presentation in English. Creating a presentation in such a short time in English was not an easy task for the learners, but after working on it step-by-step and giving the presentations, they felt joyful that they achieved their goal. The requirement to communicate with their peers in English created the circumstances in which they relied on English as their sole language for communication. The experience also provided the learners motivation to improve their English ability to instill in students an interest in study/travel abroad or an interest in communicating with people from other cultures within Japan.

The comments also showed that the context of the project increased their awareness that they have access to international products in their daily life. They realized that they 
are surrounded by international items and cultures without previously having noticed that in their daily lives. It is hoped that this gave students motivation to communicate with the global citizens who are already around them.

\section{Regarding the overall project}

- I have been very nervous about English classes but doing a presentation and communicating in English made English seem fun.

- I am afraid of English, so I was very nervous, but when I researched, I was able to write easily in most cases. The assignment of researching in English was not as bad as I thought it would be.

\section{Regarding the presentation}

- I thought making a poster layout and writing a script were good activities.

- Conducting a presentation in my own words delivered the meaning better

- Creating the poster was the most enjoyable part of the class. It was good to practice oral communication with the group members' presentations.

- This presentation was enjoyable. All the world's snacks have a history. Food is one of the important elements of a country's culture.

Regarding English communication

- I discovered that I can use English more than I thought.

- More than anything, I felt that I would like to be able to communicate in English. It looks enjoyable be able to listen, understand, and speak in English, and I can enjoy it more. I want to keep studying English more.

Regarding international relations

- Selecting the sweet was very fun and I never knew that there are so many foreign countries' sweets around me.

- I was surprised to find out that products that I see all the time are not from Japan but from foreign countries.

- To know that many of the snacks around us in daily life are really not Japanese but from foreign countries and to be able to know the culture of those countries, made me realize how global my life is.

Figure 1. Responses to the open-ended question.

\section{Limitations and Challenges}

In spite of the success of this project, there are questions that remain to be addressed. Although the project consisted of multiple elements and phases, this study did not reveal which particular factor most positively influenced the learners' affective dimension nor did it reveal which factor was most effective. Was it selecting the foreign item, the research process, writing the script in English, designing the poster, the presentation itself, or the experience of sharing and trying out the item with classmates? Further research under a different research design would be helpful in detecting more detailed elements regarding the effectiveness of this project.

In addition, I noted that many students had not yet found an item by the third week following the announcement of the project. They just kept searching on the Internet. The scope of the project did not allow for investigation of the reason for this. Further research to identify why this part of the project took so long could be useful for educators in helping students to make such choices in a more timely manner in the future.

\section{Conclusion}

This study was aimed at providing Japanese university English learners with an opportunity to realize the importance of English language learning while simultaneously influencing their affective dimensions in a positive manner. To realize this aim, I examined the effectiveness of an in-class project in raising students' awareness of the connectivity of their daily life with the rest of the world through a cultural and language learning experience. The core focus was the affective domain, but it also targeted knowledge and skills through the worksheet design which included scaffolding to help the students produce higher quality English language in their presentation through content, not just grammar and word use. The implementation revealed that this simple project had a positive impact on learners' affective domains, especially on their motivation to learn English, interest in other cultures, and use of English in communication. Therefore, the project was determined to help students lower their inhibition towards using English, increase their willingness to use English, and motivate them to improve their English skills.

The findings and the project as designed, along with the worksheets, not only support replication of the project, but also application of these elements to other projects in Japanese university classes. The results contribute to educational activities that facilitate Japanese English learners' affective domain in the classroom. 


\section{Bio Data}

Junko Chujo is a lecturer at Tokyo Denki University. Her specialized field of study is the development of in-class English pedagogical materials that focus on Japanese learners' affective variables in second language acquisition.

\section{References}

Bloom, B. S. (Ed.). (1956). Taxonomy of educational objectives: The classification of educational goals by a committee of college and university examiners. Handbook 1: Cognitive domain. New York, NY: Longmans \& Green.

Hamada, Y. (2011). Different demotivators for Japanese junior high and high school learners. Journal of Pan-Pacific Association of Applied Linguistics, 15(1), 15-38.

Heinich, R., Molenda, M., \& Russell, J. D. (1993). Instructional media and the new technologies of instruction (4th ed.). New York, NY: Wiley.

Kogo, C. (2015, April). Instructional design [Lecture]. Kyoto, Japan: Kyoto Tachibana University. Miura, T. (2010). A retrospective survey of L2 learning motivational changes. JALT Journal, 32(1), 29-53. https://doi.org/10.37546/JALTJJ32.1-2

Richard-Amarto, P. (2010). Making it happen (4th ed.). New York, NY: Pearson Education.

Yashima, T. (2002). Willingness to communicate in a second language: The Japanese EFL context. Modern Language Journal, 86, 55-66. https://doi.org/10.1111/1540-4781.00136

\section{Appendix A}

\section{Worksheet 1}

\section{International Potluck Snack Party \\ Let's taste and explore the world!$$
\sim \text { Part I }
$$

\section{A $\sim$ Expression $\sim$}

1. Find the meanings of the following expressions from 1-12 below and write the letters A-L in the space.

\begin{tabular}{|l|l|l|l|l|l|l|l|l|l|l|l|}
\hline 1 & hold & & 2 & participant & & 3 & prepare & & 4 & state(v) & \\
\hline 5 & audience & & 6 & represent & & 7 & beverage & & 8 & liquor & \\
\hline 9 & trade(n) & & 10 & allergy & & 11 & exchange(v) & & 12 & religious & \\
\hline
\end{tabular}

\begin{tabular}{|lllllll|}
\hline & A.お酒 & B.宗教上の & C.聴衆 & D.準備する & E.述べる & \\
F.開催する & G.飲料 & H.貿易 & I.アレルギー & J.代表する & K.参加者 & L.交換する \\
\hline
\end{tabular}

2. Listen to the expressions from 1-12 and place the stress mark on the syllable where the most (primary) stress is received. (Ex. stréss)

3. Practice reading the expressions from 1-12 with the correct stress with the beat. The expressions will be repeated twice.

\section{B $\sim$ Dialogue}

\section{Dictation}

Listen to the dialogue and fill in the blanks. Word choices are listed below. The dialogue will be repeated twice.

S: Tadao Y: Yoko

T: $\quad$ The members of the International Club are (1. next month. Would you like to join us?

Y: An international potluck snack party? Sounds (2. ) )! But what do I need to bring?

T: All the participants are asked to bring some snack(s), sweet(s), or drink(s) from foreign countries. The items will be exchanged with your small group members, with about four or five people. So, please bring a snack at about a price between 100 and 300 yen.

Y: I see. That's interesting!

T: Yes, but there is one thing that we need to prepare in (3. ) to bringing a snack. At the party, everyone will be asked to make a three to five minute small poster presentation in English while showing the item that you brought. In the presentation, you can state the reason why you choose the snack. Then you can either present about the snack, the country in which the snack is made or both. You can even extend your focus on your own topic related to that country, such as representing an athlete, musician, inventor, building, culture, history and so on. The poster size is A3 and small, but be sure to attract the audience with your creative poster. You are the (4. ) of the poster.

Y: I see. 
T: Last year, 15 countries were represented with (5. ) items that were brought in the (6. ). They were candies, cookies, crackers, chocolate, brownies, gummies, etc. One participant brought an electric pot and coffee from Tanzania. I also remember a studen who made a non-(7. ) beverage called piña colada. It's a drink from Mexico that he read in an English textbook and wanted to try. But he couldn't find in the store so he got a recipe from a kind liquor store (8. ) and made it on his own. He brought pineapple juice from the Philippines and coconut (9. ) from Thailand. He mixed it during his presentation and served it in Japan. It was very international. I also remember a lady who brought (10. ) trade chocolate. Her presentation was very informative. I learned how we can support people in underdeveloped countries in our daily life.

Y: Wow! That's very interesting.

T: Here, I have a worksheet to help you to get started on your presentation. If you have any allergies, such as soy, peanuts, (11. ), buckwheat, shellfish, dairy products, etc. please inform your group members. As an example, I am allergic to shrimp. If I don't eat much, will be fine, but I told them I prefer to be careful. Even if you are not (12. ) to anything, but don't want to try something out, then you don't have to eat it. You can just exchange the items (13. ) the party and take them home. There have been vegetarians and (14. ) as well. Some of the participants may not eat certain products due to religious reasons. Even just looking at the package is part of the experience. So even if you do not eat what you have received, that is fine.

Y: I see. Thank you for all the advice. Well, what should I buy... international.... different country's product...

T: I know one place in the shopping mall near our university. The store always (15. coffee at the entrance. I walked in the store once and saw lots of unfamiliar foreign products. You know what, let's go to the store and get ideas for the item and presentation.

Y: Yes, that will be helpful! Let's go and look.

\section{Word List}

serves, alcoholic, event, holding, during, vegans, fair, gluten, addition, clerk, allergic, designer, milk, food, fun

\section{Comprehension Check}

If the sentence matches with the dialogue, circle $\mathrm{T}$ (True), if not, circle $\mathrm{F}$ (False) in the parentheses.

1. The International Club is hosting an international potluck snack party. ( $\mathrm{T} / \mathrm{F}$ )

2. Participants need to give a poster presentation about the snack they bring. ( T/F )

3. Due to some food allergies, some people could not attend the party. ( T / F )
4. A student made a snack using ingredients from overseas. ( T / F )

5. One lady's presentation informed the group on how to help undeveloped countries. $(\mathrm{T} / \mathrm{F})$

\section{Summary}

Summarize three underlined sections in the dialogue. The summary is an overview of your presentation theme on this unit. You can summarize either in English or Japanese.

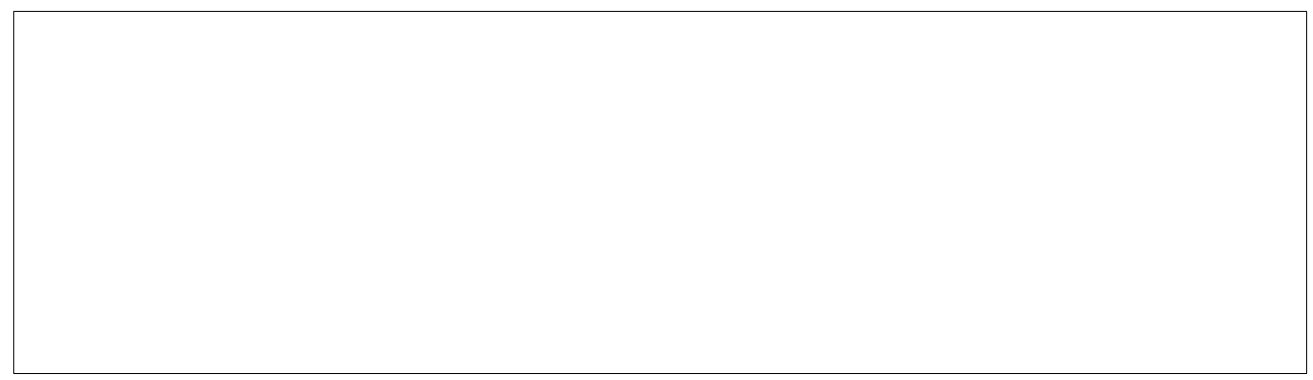

\section{Let's Practice for the Presentation}

This is part of Yusuke's presentation script. To get an idea for your presentation, use the script and practice the presentation. Stand up and hold your textbook and read the presentation pretending you have an audience in front of you. Time your presentation and find out how long the script needs to be and what speed is good for your audience.

Hello, everyone. I am Yusuke Mori. I am majoring in architecture. This is my last year in college. Today I would like to introduce Hungary and its' special product: honey. I bought this honey at a convenience store. I like this one and use it every day for my toast. I had this every day without knowing it came from Hungary. So, I did a search on Hungary.

Do you know where Hungary is located? This is Hungary. (Point to the map on the poster)

This is the national flag. They speak Hungarian. The capital city is Budapest. Here are some people from Hungary. Hungary has a culture similar to Japan. They like hot springs, "onsen." They have 2000 years of history!

Also, I did not know that Rubick's Cube, a 3-D combination puzzle, was invented by a Hungarian architecture professor in 1974! I have had one since I was in elementary school. So I already had a connection with the country Hungary, even before realizing the honey for my toast comes from there! Even though I have had it so long, I am only able to solve the first face, never the second. Is anybody good at it? 


\section{Appendix B \\ Worksheet 2}

\section{D $\sim$ Presentation $\sim$}

\section{$\sim$ Part II}

\section{$\sim$ Presentation Theme $\sim$}

International Snacks from Around the World

\section{Presentation Assignment \& Plan}

My Presentation Date: (Group: Presentation Number:

Presentation Type:

Presentation Time: "Refer to the Introductory Unitt minutes

Script: 1. With a Script (Glancing) 2. Without a Script 3. Your Choice Other requirement(s):

Script Submission Due Date: Poster Submission Due Date:

Presentation Item: Price: (yen) Country:

Decide the item by: Write scripts by: Design poster by: Presentation rehearsals and (Dates)

\section{Presentation Organization Plan}

\begin{tabular}{|c|c|c|}
\hline $\begin{array}{l}\text { Introduction } \\
(\quad \text { minute }(\mathrm{s}))\end{array}$ & $\begin{array}{l}\text { Body } \\
(\quad \text { minute }(s))\end{array}$ & $\begin{array}{l}\text { Conclusion } \\
\left(\begin{array}{l}\text { minute }(\mathrm{s})\end{array}\right)\end{array}$ \\
\hline $\begin{array}{l}\text { - Greeting } \\
\text { - Self-introduction } \\
\text { - Introduction of your } \\
\text { topic } \\
\text { (Brief introduction of the } \\
\text { item and the country.) }\end{array}$ & & \\
\hline
\end{tabular}

\section{Presentation Script}

Title

Hello everyone. My name is

Today, I would like to talk about

*A hand-out version of the sheet is placed at the end of this textbook.

\section{Poster Layout (Practice)}

SIDN: NAME:

Think about your audience in writing and presenting your presentation. Enjoy! 


\section{Appendix C \\ Worksheet 3}

\section{$\sim$ Presentation Report $\sim$}

At the party, listen to your group members' presentations and take notes. After all the members' presentations, let's taste the snacks from around the world!

Presentation day:

\begin{tabular}{|l|l|l|l|l|}
\hline $\begin{array}{l}\text { Group Members } \\
\text { Name } \\
\text { Yours }\end{array}$ & $\begin{array}{c}\text { Country of } \\
\text { the Item }\end{array}$ & $\begin{array}{c}\text { Description of the } \\
\text { Item and Country }\end{array}$ & $\begin{array}{c}\text { Comments on the Item } \\
\text { How did you like it? } \\
\text { (After tasting) }\end{array}$ \\
\hline 2 & & & & \\
\hline 3 & & & & \\
\hline 4 & & & & \\
\hline 5 & & & & \\
\hline
\end{tabular}

$\sim$ Comments on the presentation/activity

Today, I had an opportunity to taste snacks from different countries!
Appendix D

Students' Questionnaire Results (Class A, $\mathrm{n}=27$, Class B, $\mathrm{n}=18$ )

\begin{tabular}{lccccccc} 
& Class & 1 & 2 & 3 & 4 & 5 & N/A \\
\hline I had knowledge of the selected country before the project. & $A$ & 3 & 10 & 1 & 12 & 1 & 0
\end{tabular}

Increased my knowledge of the selected country after the project.

3 I increased my closeness to my presented county after the presentation.

$4 \quad$ I was able to do the presentation as I planned and prepared.

5 | increased my interest (closeness) to my group members presented county after the presentation.

$6 \quad$ I learned more than I expected about the country that my group members presented after the presentations.

7 I felt that my group members came to know about the country that I presented.

$8 \quad$ | felt gloomy when this project was assigned.

I felt nervous conducting the presentation.

10 I had a feeling of accomplishment after the presentation

11 I enjoyed the presentation session

12 I ate the snack that I exchanged with my group members.

13 I was interested in the country, culture, language of the country that my group members presented.

14 Do you think this project experience is good for communicating with foreigners?

15 Do you think you would like to be able to communicate more in English?

16 I can do better when the same project is assigned in the future.

\begin{tabular}{ccccc|c|c}
$\mathrm{B}$ & 4 & 2 & 3 & 1 & 1 & 0 \\
$\mathrm{~A}$ & 0 & 1 & 1 & 19 & 6 & 0 \\
$\mathrm{~B}$ & 1 & 0 & 0 & 14 & 3 & 0 \\
$\mathrm{~A}$ & 1 & 1 & 2 & 18 & 5 & 0 \\
$\mathrm{~B}$ & 1 & 0 & 3 & 10 & 4 & 0 \\
$\mathrm{~A}$ & 0 & 1 & 2 & 19 & 5 & 0 \\
$\mathrm{~B}$ & 0 & 0 & 1 & 12 & 5 & 0 \\
$\mathrm{~A}$ & 0 & 3 & 0 & 19 & 5 & 0 \\
$\mathrm{~B}$ & 1 & 0 & 3 & 10 & 4 & 0 \\
$\mathrm{~A}$ & 0 & 1 & 3 & 16 & 5 & 0 \\
$\mathrm{~B}$ & 1 & 0 & 4 & 10 & 3 & 0 \\
$\mathrm{~A}$ & 1 & 1 & 7 & 14 & 4 & 0 \\
$\mathrm{~B}$ & 0 & 1 & 5 & 10 & 2 & 0 \\
$\mathrm{~A}$ & 5 & 3 & 8 & 9 & 2 & 0 \\
$\mathrm{~B}$ & 1 & 7 & 4 & 4 & 1 & 1 \\
$\mathrm{~A}$ & 2 & 7 & 2 & 10 & 6 & 0 \\
$\mathrm{~B}$ & 3 & 3 & 3 & 8 & 1 & 0 \\
$\mathrm{~A}$ & 0 & 1 & 5 & 17 & 4 & 0 \\
$\mathrm{~B}$ & 1 & 3 & 5 & 7 & 2 & 0 \\
$\mathrm{~A}$ & 0 & 0 & 4 & 10 & 13 & 0 \\
$\mathrm{~B}$ & 0 & 1 & 1 & 10 & 6 & 0 \\
$\mathrm{~A}$ & & & & 24 & & 0 \\
$\mathrm{~B}$ & & 1 & & 16 & & 1 \\
$\mathrm{~A}$ & 1 & 1 & 3 & 18 & 1 & 1 \\
$\mathrm{~B}$ & 1 & 1 & 4 & 11 & 1 & 0 \\
$\mathrm{~A}$ & 0 & 2 & 6 & 16 & 3 & 0 \\
$\mathrm{~B}$ & 1 & 1 & 5 & 10 & 0 & 1 \\
$\mathrm{~A}$ & 0 & 1 & 2 & 16 & 8 & 0 \\
$\mathrm{~B}$ & 1 & 1 & 0 & 11 & 5 & 0 \\
$\mathrm{~A}$ & 0 & 1 & 5 & 19 & 2 & 0 \\
$\mathrm{~B}$ & 0 & 0 & 3 & 14 & 1 & 0 \\
\hline
\end{tabular}

Note 1 = strongly disagree, 2 = disagree, $3=$ neutral 4 = agree, $5=$ strongly agree. The gray highlighted section shows the largest number of responses. 